\title{
Profil Kasus Endometriosis di RSUD Arifin Achmad Provinsi Riau Periode 1 Januari 2012 - 31 Desember 2016
}

\author{
Dini Fatimah ${ }^{1}$, Imelda E.B Hutagaol ${ }^{2}$, Ilhami Romus ${ }^{3 *}$
}

\begin{abstract}
Endometriosis is endometrial tissue (glands and stroma) that grow outside of the uterus. The goal of this research was to see the profile of endometriosis cases in Arifin Achmad general hospital in Riau province. The research method used is descriptive with cross-sectional approach. Based on patient characteristics, highest education was SMA (47,9\%), majority patients cames from Pekanbaru city (58,8 \%), the patients were at reproductive age (92.6\%), most patients were nullipara (54.8\%). Anatomical location were $45.1 \%$ located in the ovarium. The most common clinical symptom was dysmenorrhea (36.2\%), 49.5\% were stage 4, and the most frequently performed was laparotomy (71.8\%). The conclusion of this study were endometriosis found primarily in reproductive and nulliparous ages, the most common anatomic location was in the ovarium and classified in stage 4, the most clinical symptom was dysmenorrhea, and the most common operative action was laparotomy.
\end{abstract}

Keywords: endometriosis, profile, RSUD Arifin Achmad.

Endometriosis merupakan terdapatnya sebagian jaringan endometrium (kelenjar dan stroma) yang tumbuh diluar uterus. Endometriosis dapat menimbulkan infertilitas pada wanita, sebaliknya beberapa wanita yang tidak terdiagnosis endometriosis biasanya datang dengan keluhan tidak dapat hamil. Endometriosis juga dapat menurunkan angka produktifitas kerja secara signifikan pada wanita di berbagai negara. ${ }^{1}$ Gejala klinis dari endometriosis dapat berupa, severe dysmenorrhoea' dyspareunia dalam, chronic pelvic pain, nyeri saat ovulasi, gejala perimenstrual (nyeri pada saat defekasi atau nyeri pada kandung kemih) dengan atau tanpa disertai perdarahan abnormal, infertilitas, kelelahan yang bersifat kronik. ${ }^{2}$

Angka kejadian endometriosis $5-10 \%$ dari usia reproduksi wanita di dunia. ${ }^{3}$ Insidensi endometriosis tertinggi pada wanita yang mengalami infertilitas mencapai $20-50 \% .{ }^{4}$ Prevalensi wanita yang menjalani sterilisasi mencapai 3,7 $-6 \%{ }^{5}$ Survey yang dilakukan pada wanita di United

\footnotetext{
* Penulis untuk korespondensi : ilhamiromus@yahoo.co.id

1 Fakultas Kedokteran Universitas Riau

2 KJF Kebidanan dan Kandungan Fakultas Kedokteran Universitas Riau

3 KJF Patologi Anatomi Fakultas Kedokteran Universitas Riau
}

Kingdom dan United State yang dirujuk ke pusat endometriosis berbasis universitas ditemukan bahwa $70-71 \%$ menderita nyeri pelvis, 71 - 76\% dengan dysmenorrhea, 44\% dengan dyspareunia, dan 15 $-20 \%$ mengalami infertilitas. ${ }^{3}$

Dysmenorrhea merupakan keluhan utama yang dilaporkan oleh penelitian yang dilakukan oleh Bellelis pada studi kasus di Brazil dengan hasil 62\% ditemukan endometriosis peritoneal. Pada penelitian yang sama, prevalensi dari nyeri pelvis kronis $57 \%$, dyspreunia 55\%, gangguan gastrointestinal $48 \%$, infertilitas $40 \%$ dan yang tidak mengalami dysmenorrhea 28\%. ${ }^{6}$ Pada penelitian yang dilakukan di RSUP DR. M. Djamil Padang didapatkan sebanyak 33 kasus dari tahun 2010 2013 dengan hasil 64\% adalah pada usia reproduktif dan sebagian besar nulipara, 82\% ditemukan pada ovarium, dan $18 \%$ ditemukan diluar organ genital serta gejala klinis dysmenorrhea ditemukan pada $70 \%$ kasus. $^{7}$

Sampai saat ini belum diketahui dan belum ada konsensus yang menyatakan asal sel dari endometriosis. Kegagalan mekanisme kekebalan tubuh untuk menghancurkan jaringan ektopik dan maldiferensiasi jaringan endometriosis diduga sebagai 
mekanisme yang mendasari defek dari sel stroma yang terkait dengan peningkatan kadar esterogen dan prostaglandin serta bersamaan dengan resistensi progesteron. ${ }^{8}$ Teori retrograde menstruation menyebutkan terjadi reflux jaringan menstruasi melalui tuba falopi dan implan pada struktur organ panggul.Mekanisme ini telah dipelajari secara konsisten dan didukung oleh distribusi implan dari lesi endometriosis. Namun, teori ini tidak menjelaskan pengamatan terhadap reflux menstruasi secara jelas tetapi hanya dilaporkan dapat mengenai $5-10 \%$ populasi wanita. ${ }^{9}$

\section{METODE}

Jenis penelitian ini adalah deskriptif dengan pendekatan cross - sectional. Penelitian ini dilakukan di RSUD Arifin Achmad pada bulan Oktober - Desember 2017 di bagian rekam medik pasien bagian Obstetri - Ginekologi. Populasi pada penelitian ini adalah semua data rekam medik pasien endometriosis yang berobat di bagian ObstetriGinekologi RSUD Arifin Achmad periode 1 Januari 2012 - 31 Desember 2016. Penarikan sampel pada penelitian ini menggunakan metode total sampling. Dimulai dengan mencatat nomor identitas rekam medik pasien endometriosis dari bagian ObstetriGinekologi di RSUD Arifin Achmad periode 2012 2016. Kemudian identitas tersebut ditelusuri di bagian rekam medik. Setelah rekam medik pasien didapatkan kemudian data yang dibutuhkan untuk penelitian dicatat pada lembar kerja penelitian. Pengolahan data gambaran kasus endometriosis di RSUD Arifin Achmad Provinsi Riau dilakukan secara manual dan disajikan dalam bentuk tabel distribusi frekuensi dengan analisis univariat.

\section{HASIL}

Pada penelitian ini didapatkan sampel sebanyak 188 pasien dengan karakteristik dapat dilihat pada tabel 1 .

Tabel 1. Tabel distribusi frekuensi karakteristik pasien endometriosis di RSUD Arifin Achmad

\begin{tabular}{|c|c|c|}
\hline Gambaran & Jumlah (N) & Persentase $(\%)$ \\
\hline \multicolumn{3}{|l|}{ Tingkat Pendidikan } \\
\hline $\mathrm{SD}$ & 25 & 13,3 \\
\hline SMP & 27 & 14,4 \\
\hline SMA & 90 & 47,9 \\
\hline Sarjana/Diploma & 46 & 24,5 \\
\hline \multicolumn{3}{|l|}{ Usia } \\
\hline$<15$ tahun & 0 & 0 \\
\hline 15-49 tahun & 174 & 92,6 \\
\hline$>50$ tahun & 14 & 7,4 \\
\hline \multicolumn{3}{|l|}{ Paritas } \\
\hline Nulipara & 103 & 54,8 \\
\hline Primipara & 33 & 17,6 \\
\hline Multipara & 41 & 21,8 \\
\hline Grandemultipara & 11 & 5,9 \\
\hline \multicolumn{3}{|l|}{ Asal Daerah } \\
\hline Pekanbaru & 110 & 58,8 \\
\hline Bengkalis & 8 & 4,3 \\
\hline Indragiri hulu & 8 & 4,3 \\
\hline Indragiri hilir & 11 & 5,9 \\
\hline Kampar & 12 & 6,4 \\
\hline Kuantan Singingi & 4 & 2,1 \\
\hline Pelalawan & 6 & 3,2 \\
\hline Rokan hilir & 4 & 2,1 \\
\hline Siak & 14 & 7,4 \\
\hline Rokan hulu & 2 & 1,1 \\
\hline Dumai & 9 & 4,8 \\
\hline Total & 188 & 100 \\
\hline
\end{tabular}


Berdasarkan hasil penelitian didapatkan karakteristik pasien endometriosis sebagian besar adalah pasien dengan usia reproduktif yaitu 15-49 tahun sebesar $92,6 \%$, sebagian besar pasien merupakan nullipara 54,8\%, pendidikan terakhir pasien adalah SMA 47,9\%, dan asal daerah pasien yang paling banyak adalah berasal dari Kota Pekanbaru 58,8\%.

Tabel 2. Gambaran lokasi anatomi kasus endometriosis di RSUD Arifin Achmad Provinsi Riau tahun 2012 $-2016$.

\begin{tabular}{lc}
\hline \multicolumn{1}{c}{ Lokasi anatomi } & Persentase $(\%)$ \\
\hline Dinding uterus & 22,5 \\
Ovarium & 45,1 \\
Uterine Ligament & 0,9 \\
Pelvic peritoneum & 7,2 \\
Usus besar, usus kecil, dan appendix & 6,6 \\
Mukosa serviks, vagina dan tuba fallopi & 17,3 \\
Eksterna & 0,3 \\
\hline & 100 \\
\hline
\end{tabular}

Berdasarkan hasil penelitian didapatkan lokasi endometriosis secara anatomi terbanyak di ovarium yaitu sebesar $45,1 \%$ dan paling sedikit berada di eksterna yaitu sebesar $0,3 \%$.

Tabel 3. Gambaran gejala klinis pasien endometriosis di RSUD Arifin Achmad Provinsi Riau tahun 2012 2016.

\begin{tabular}{lc}
\hline \multicolumn{1}{c}{ Gejala Klinis } & Persentase \\
\hline Nyeri pelvis & 35,1 \\
Dysmennorhea & 36,2 \\
Dyspareunia & 1,8 \\
Dyschezia & 3,1 \\
Dysuria & 1,5 \\
DUB (Dysfunctional Utero Bleeding) & 9,5 \\
Infertilitas & 12,8 \\
\hline & Total \\
\hline
\end{tabular}

Berdasarkan hasil penelitian didapatkan gejala klinis pasien endometriosis yang paling banyak adalah dysmenorrhea yaitu sebesar 36,2\% dan yang paling sedikit adalah dysuria yaitu sebesar $1,5 \%$.

Tabel 4. Gambaran klasifikasi pasien endometriosis di RSUD Arifin Achmad Provinsi Riau tahun 2012 2016 berdasarkan rASRM.

\begin{tabular}{ccc}
\hline Klasifikasi & Jumlah & Persentase \\
& & 11,2 \\
Stadium 1 & 21 & 13,8 \\
Stadium 2 & 26 & 25,5 \\
Stadium 3 & 48 & 49,5 \\
Stadium 4 & 93 & 100 \\
\hline Total & 188 & \\
\hline
\end{tabular}


Berdasarkan hasil penelitian didapatkan bahwa klasifikasi endometriosis terbanyak adalah stadium
4 yaitu sebesar 93 pasien (49,5\%) dan yang paling sedikit adalah stadium 1 yaitu sebesar 21 pasien (11,2\%).

Tabel 5. Gambaran penatalaksanaan pasien endometriosis di RSUD Arifin Achmad Provinsi Riau tahun $2012-2016$.

\begin{tabular}{ccc}
\hline Penatalaksanaan & Jumlah & Persentase \\
\hline Laparotomy & 135 & 71,8 \\
Laparascopy & 53 & 28,2 \\
\hline Total & 188 & 100 \\
\hline
\end{tabular}

Berdasarkan hasil penelitian didapatkan penatalaksanaan kasus endometriosis paling banyak dengan teknik laparotomy yaitu sebesar 135 pasien (71,8\%) dan yang paling sedikit dengan teknik laparascopy yaitu sebesar 53 pasien (28,2\%).

\section{PEMBAHASAN}

\section{Karakteristik Pasien Endometriosis Pendidikan}

Berdasarkan hasil penelitian, didapatkan bahwa tingkat Pendidikan pasien endometriosis yaitu SD sebesar 25 orang (13,3\%), SMP sebesar 27 orang (14,4\%), SMA sebesar 90 orang $(47,9 \%)$, dan Sarjana/diploma sebesar 46 orang (24,5\%). Hasil penelitian ini sesuai dengan penelitian yang dilakukan di Semarang dari 100 sampel didapatkan pendidikan pasien endometriosis yaitu SD sebesar 24 orang (24\%), SMP sebesar 13 orang (13\%), SMA sebesar 33 orang (33\%), dan Sarjana/diploma sebesar 30 orang $(30 \%) .{ }^{10}$

Pendidikan dapat mempengaruhi seseorang termasuk juga perilaku akan pola hidup terutama dalam memotivasi untuk sikap peran serta dalam bidang kesehatan. Menurut sebuah penelitian mengungkapkan bahwa semakin tinggi tingkat Pendidikan, maka semakin tinggi pula konsep diri yang dimiliki oleh wanita tersebut. Sehingga, semakin tinggi tingkat Pendidikan maka semakin mudah untuk menerima informasi dan pengetahuan yang dimiliki, sebaliknya tingkat Pendidikan yang kurang akan menghambat perkembangan sikap seseorang terhadap nilai - nilai yang baru diperkenalkan. Sehingga Pendidikan sangat diperlukan untuk mendapatkan informasi seperti dalam bidang kesehatan sehingga dapat meningkatkan kualitas hidup. $^{11}$

\section{Asal daerah}

Berdasarkan hasil penelitian didapatkan bahwa asal daerah pasien dengan endometriosis paling terbanyak yaitu Kota Pekanbaru sebesar 110 orang pasien (58,8\%), lalu diikuti dengan Kabupaten Siak yaitu sebesar 14 orang pasien (7,4\%), kemudian Kabupaten Kampar sebesar 12 orang pasien (6,4\%), pada Kabupaten Indragiri Hilir didapatkan sebesar 11 orang pasien (5,9\%), untuk hasil yang sama pada Kabupaten Bengkalis dan Indragiri Hulu terdapat 8 orang pasien (4,3\%), pada Kota Dumai didapatkan hasil sebanyak 9 pasien (4,8\%), Kabupaten Pelalawan sebesar 6 pasien (3,2\%), serta hasil yang sama pada Kabupaten Kuantan Singingi dan Kabupaten Rokan Hilir sebesar 4 orang pasien (2,1\%), dan yang paling terendah terdapat pada Kabupaten Rokan Hulu sebesar 2 orang pasien (1,1\%).

Hal ini sejalan dengan penelitian yang dilakukan di UNSRI didapatkan dari 62 sampel, terdapat 43 orang $(69,4 \%)$ berdomisili atau bertempat tinggal di Palembang. Sisanya yaitu 19 orang (30\%) berdomisili di luar Palembang. ${ }^{12}$

Menurut sebuah penelitian, terdapat suatu faktor resiko tentang terjadinya endometriosis dimana adanya paparan dari zat - zat polutan polychlorinated biphenyls dan dioxin. Beberapa studi mengungkapkan bahwa paparan dari dioxin dapat menyebabkan endometriosis. Bukti baru juga menunjukkan bahwa zat polutan lingkungan lainnya seperti phthalates, bisphenol A atau polutan 
organochlorinated) berkontribusi terhadap kejadian endometriosis. Paparan polychlorinated biphenyls dandioxin dapat memodulasi respon imunologi, mempengaruhi secara biologis terhadap efek potensial terhadap pathogenesis terjadinya endometriosis. ${ }^{13}$

\section{Usia}

Berdasarkan hasil penelitian didapatkan bahwa karakteristik usia pasien endometriosis yang paling tinggi adalah usia reproduktif yaitu usia 15 - 49 tahunyaitu sebesar 174 orang pasien (92,6\%) dan yang paling rendah adalah usia diatas 50 tahun yaitu sebesar 14 orang pasien (7,4\%). Hasil analisis univariat didapatkan usia termuda pasien endometriosis adalah 16 tahun dan umur tertua 74 tahun. Rata - rata umur pasien endometriosis didapatkan berusia 34,75 - 37,68 tahun.

Hal ini sejalan dengan penelitian yang dilakukan di Thailand yaitu sebanyak 46 sampel yang ditemukan berusia $<45$ tahun sebesar 35 pasien (76,1\%), dan sisanya 11 pasien berusia e” 45 tahun sebesar 11 pasien $(23,9 \%){ }^{14}$

Usia awal terkena endometriosis dapat mengenai perempuan yang masih belasan tahun saat perempuan tersebut mencapai menars, dan berlanjut ke masa remaja, masa dewasa dan makin berekmbang pada usia reproduksi (usia subur) dan terus berlanjut, sehingga dapat dikatakan menetal sepanjang kehidupan perempuan. ${ }^{15}$

\section{Paritas}

Berdasarkan hasil penelitian 188 pasien didapatkan bahwa status paritas pasien endometriosis yang paling banyak adalah nullipara sebanyak 103 pasien $(54,8 \%)$, primipara 33 pasien $(17,6 \%)$, multipara 41 pasien $(21,8 \%)$ dan grande multipara 11 pasien (5,9\%). Hal ini sejalan dengan penelitian di India dengan besar sampel 50 pasien. Nullipara sebanyak 36 pasien (72\%), primipara 13 pasien (26\%) dan multipara 1 pasien (2\%). ${ }^{16}$

Berdasarkan beberapa hasil penelitian, beberapa klinis dan data epidemiologi menunjukkan bahwa ada kaitan antara riwayat paritas dengan faktor resiko terjadinya endometriosis. ${ }^{17}$

\section{Kasus Endometriosis Berdasarkan Gejala Klinis}

Berdasarkan hasil penelitian didapatkan gejala klinis yang dirasakan pasien endometriosis yang paling banyak adalah dysmenorrhea $36,2 \%$, nyeri pelvis 35,1\%, infertilitas 12,8\%, DUB (Dysfunctional Utero Bleeding) 9,5\%, dyspareunia 1,8\%, dyschezia $3,1 \%$ dan yang paling sedikit yaitu dysuria sebesar 1,5\%. Hal ini sejalan dengan penelitian yang dilakukan di Cairo, Mesir didapatkan dari 50 jumlah sampel didapatkan 48\% mengeluhkan dysmenorrhea, 26\% dengan nyeri pelvis, 18\% dyspareunia, $6 \%$ dyschezia, dan yang paling sedikit dysuria $2 \% .{ }^{17}$

Gejala klinis yang dirasakan pasien sebagian besar adalah dysmenorrhea hal ini terkait dengan peranan dari sitokin - sitokin proinflamasi yang bekerja pada lesi endometriosis tersebut menghasilkan produksi prostaglandin E2 (PGE2) dalam jumlah yang besar sehingga dapat meningkatkan invasi neuronal dengan merangsang pembentukan NGF dan neurotropin lainnya. Hal ini menyebabkan terjadinya nyeri inflamasi persisten dan menghambat apoptosis neuron. ${ }^{18}$

\section{Profil Kasus Endometriosis berdasarkan Lokasi Anatomi}

Berdasarkan hasil penelitian didapatkan pertumbuhan / adhesi dari implant endometriosis sebagian besar ditemukan di ovarium sebesar 45,1\%, dinding uterus $22,5 \%$, mukosa serviks, vagina dan tuba fallopi $17,3 \%$, pelvic peritoneum $7,2 \%$, usus besar, usus kecil dan appendix 6,6\%, uterine ligament 0,9\% dan endometriosis eksterna 0,3\%. Penelitian ini sesuai dengan penelitian yang dilakukan di Amerika. Dari 806 pasien didapatkan lokasi anatomi terbanyak adalah pada traktus genital (uterus, tuba fallopi, dan ovarium) sebesar 406 pasien (53,4\%), pada kandung kemih dan ureter sebesar 49 pasien (6,1\%), pada usus ditemukan sebesar 44 pasien (5,5\%), implant diluar rongga pelvik atau omentum sebesar 30 pasien $(3,7 \%)$, dan endometriosis lain (other) sebesar 39 pasien $(9,1 \%) .{ }^{19}$

Berkaitan dengan teori retrograde menstruation, dimana terjadi reflux jaringan menstruasi melalui tuba falopi dan implan pada 
struktur organ panggul. Mekanisme ini telah dipelajari secara konsisten dan didukung oleh distribusi implan dari lesi endometriosis. ${ }^{20}$

\section{Profil Kasus Endometriosis Berdasarkan Derajat/Klasifikasi}

Berdasarkan hasil penelitian didapatkan bahwa stadium/klasifikasi pasien endometriosis yaitu stadium 1 sebesar 21 pasien (11,2\%), stadium 2 sebesar 26 pasien (13,8\%), stadium 3 sebesar 48 pasien (25,5\%), dan stadium 4 sebesar 93 pasien (49,5\%). Hal ini sejalan dengan penelitian yang dilakukan di India ditemukan dari hasil laparascopy sebanyak 195 jumlah sampel didapatkan endometriosis stadium 4 sebesar 47 pasien $(24,1 \%)$, stadium 3 sebesar 69 pasien (35,3\%), stadium 2 sebesar 18 pasien (9,23\%), dan stadium 1 sebesar 61 pasien $(31,17 \%){ }^{21}$

Klasifikasi endometriosis berdasarkan rASRM, yang meliputi tipe, lokasi, tampilan, kedalaman invasi lesi, serta perlengketan endometriosis. Klasifikasi tersebut sebagai berikut :

1. Stadium 1 : Implantasi terbatas dan tidak ada perlengketan.

2. Stadium 2 : Implantasi superfisial berkelompok dengan luas kurang dari $5 \mathrm{~cm}$, tersebar pada ovarium dan peritoneum. Tidak ada perlengketan yang nyata.

3. Stadium 3 : Implantasi superfisial dan dalam jumlah yang multiple. Terdapat perlengketan peritubal dan periovarium.

4. Stadium 4 : Implantasi superfisial dan dalam yang multipel, terdapat endometrioma ovarium yang besar. Terdapat perlengketan yang hebat. ${ }^{22}$

\section{Profil Kasus Endometriosis Berdasarkan Penatalaksanaan}

Berdasarkan hasil penelitian mengenai tatalaksana operatif untuk pasien endometriosis didapatkan bahwa yang menjalani tindakan laparotomy sebesar 135 pasien (71,8\%), dan laparascopy sebesar 53 pasien $(28,2 \%)$. Hal ini sejalan dengan penelitian yang di lakukan di Itali didapatkan sebesar 216 sampel data bahwa 67 pasien menjalani tindakan laparoscopy dan 149 pasien menjalani tindakan laparotomy untuk stadium 3 dan stadium $4 .{ }^{23}$

Pemeriksaan laparoskopi sangat diperlukan untuk diagnosis pasti endometriosis agar dapat menyingkirkan diagnosis banding antara radang pelvis dan keganasan di daerah pelvis. ${ }^{24}$

\section{KESIMPULAN}

Berdasarkan data rekam medik pasien endometriosis di RSUD Arifin Achmad Provinsi Riauperiode 1 Januari 2012 - 31 Desember 2016dapat diambil kesimpulan, karakteristik pasien endometriosis sebagian besar adalah pasien dengan usia reproduktif yaitu (15-49 tahun), sebagian besar pasien merupakan nullipara, pendidikan terakhir pasien adalah SMA, dan asal daerah pasien yang paling banyak adalah berasal dari Kota Pekanbaru. Gejala klinis yang paling banyak merupakan dysmenorrhea.Lokasi anatomi yang paling sering adalah ovarium.Stadium endometriosis yang paling banyak adalah stadium 4.Penatalaksanaan yang paling sering dilakukan untuk penanganan pasien adalah tindakan laparotomy.

\section{DAFTAR PUSTAKA}

1. Robbins, Cotran. Pathologic basis of disease. Elsevier, 2010;8:section 22.

2. Kennedy et al. Fertile Steril. ESHRE Guideline 2005;20:2698-2704.

3. Waller KG, Lindsay P, Curtis P, Shaw RW. The prevalence of endometriosis in women with infertile partners. Eur J Obstet Gynecol Reprod Biol 1993;48:135-9.

4. Rawson JM. Prevalence of endometriosis in asymptomatic women. J Reprod Med 1991;36:513-5.

5. Sangi-Haghpeykar H, Poindexter AN III. Epidemiology of endometriosis among parous women. Obstet Gynecol 1995;85:983-92.

6. Bellelis P, Dias JA, Jr., Podgaec S, Gonzales M, Baracat EC and Abrão MS. Epidemiological and clinical aspects of pelvic endometriosis - a case series. Rev Assoc Med Bras 2010; 56:467-71. 
7. Abadi, KC, 2014. Gambaran endometriosis di laboratorium patologi anatomi RSUP DR. M. DJAMIL PADANG periode 2010 - 2013. Skripsi. Padang.

8. Bulun SE. Endometriosis. N Engl J Med 2009;360:268-79.

9. Sampson JA. Peritoneal endometriosis due to menstrual dissemination of endometrial tissue into the peritoneal cavity. Am J Obstet Gynecol 1927;14:422-69.

10. Octavianny A. Hubungan kista endometriosis dengan kejadian infertilitas di RSUD Tugurejo Semarang dan RSUD Kota Semarang. Fakultas Kedokteran Universitas Muhammadiyah Semarang. Skripsi. Semarang. 2016:49. (diakses pada tanggal 20 Desember 2017)

11. Jaya P., Manggiasih VA., Andriani S. Hubungan antara tingkat Pendidikan dengan konsep diri pada wanita infertile di rumah sakit putri Surabaya. Surabaya. Talenta psikologi. Vol 4;1:2015:91-7 (diakses pada tanggal 20 desember 2017)

12. Oktarina A., Abadi A., Bachsin R. Faktor - faktor yang mempengaruhi infertilitas pada wanita di klinik fertilitas endokrinologi reproduksi. Departemen Obstetri dan Ginekologi FK Unsri/ RSMH. Palembang. 2014.46;4:297.(diakses pada tanggal 20 Desember 2017)

13.Parazzini F., Esposito G., Tozzi L., Noli S., Bianchi S. Epidemiology of endometriosis and its comorbidities. Europian Journal of Obstetrics \& Gynecology and Reproductive Biology. Elsevier. Italy. 2016:3. (diakses pada tanggal 20 Desember 2017)

14.Tanmahasamut P.,Noothong S., Sanga-areekul N., Silprasit K., Dangrat C. Prevalence of endometriosis in women undergoing surgery for benign gynecologic disease. Department of Obstetrics and Gynaecology, Faculty of Medicine Siriraj Hospital, Mahidol University, Bangkok. Thailand. J Med Assoc Thai 2014;149. (diakses pada tanggal 20 Desember 2017)

15. Oepomo, Tedjo D, 2007. Dampak endometriosis pada kualitas hidup perempuan dalam pidato pengukuhan guru besar dalam obstetri dan ginekologi universitas sebelas Maret, Surakarta.
16. Naseer, Khan A., Illahi N. Prevalence and presentation of endometriosis in patients admitted in nishtar hospital,Multan. Department of Obstetrics and Gynaecology, Nishtar Medical College, Multan. India. JAMC Vol. 12 No. 3, 2000:24. (diakses pada tanggal 20 Desember 2017)

17.Ghonemy GE., El Sharkawy NB. Impact of changing lifestyle on endometriosis related pain. Lecturer of Maternal and Newborn Health Nursing Department, Faculty of Nursing, Cairo University, Cairo, Egypt. IOSR journal Vol. 6:issue 2. 2017:124. (diakses pada tanggal 21 Desember 2017)

18. Giudice Linda C. 2010. Endometriosis. $N$ Engl $J$ Med 2010;362:2389-98.

19. Mowers EL, et al. Prevalence of endometriosis during abdominal or laparoscopic hysterectomy for chronic pelvic pain. The American College of Obstetricians and Gynecologists. 2016:Vol 127,No.6:1051. (diakses pada tanggal 21 Desember 2017)

20. Sampson JA. Peritoneal endometriosis due to menstrual dissemination of endometrial tissue into the peritoneal cavity. Am J Obstet Gynecol 1927;14:422-69.

21.Rajeswari M., Ramanidevi T., Kadalmani B. Cohort study of endometriosis in south Indian district. International Journal of Reproduction, Contraception, Obstetrics and Gynecology Mohan M et al. Int J Reprod Contracept Obstet Gynecol. 2016 Nov;5(11):3884-5. (diakses pada tanggal 20 Desember 2017)

22. Revised ASRM Classification. Fertil Steril 1997; 67: 819 .

23.Crosignani PG, et al. Laparoscopy versus laparotomy in conservative surgical treatment for severe endometriosis. Italy.1996:709 (diakses pada tanggal 21 Desember 2017)

24.Adamson GD. Laparoscopic treatment of endometriosis. In: Adamson GD, Martin DC, editors. Endoscopic Management of Gynecologic Disease Philadelphia: Lippincott-Raven Publishers; 1996:147-87.(diakses pada tanggal 21 Desember 2017) 